\title{
Reading the Melopoiae (1507): a search for its owners and users
}

\author{
Elisabeth Giselbrecht
}

The Melopoiae, printed at Augsburg in 1507, has always held a special place in the hearts and minds of early music scholars - and for good reason. ${ }^{1}$ As a material object it is remarkable: printed by Erhard Oeglin and published by Johannes Rynmann in Augsburg, it was among the first publications to use the multiple-impression technique for printing polyphony north of the Alps. ${ }^{2}$ Moreover, it is in small folio format, rather unusual for polyphony, and contains many paratexts, including a memorable title page, a number of dedicatory poems and two full-page woodcuts. ${ }^{3}$ Its musical content also attracts attention. With its twenty-two metrical settings of odes - nineteen settings of Horace, followed by three settings of poems by Celtis, Lucan and Alcuin - exemplifying the different Latin metres, set to music by the Austrian schoolmaster Peter Treibenraif (Petrus Tritonius), it is the first source on this scale of the so-called humanist ode setting. And behind it all stands the impressive figure of the German 'arch-humanist' Konrad Celtis.

Over the past decade, the Melopoiae had to give up some of its claims: although long heralded as the first publication of polyphony printed from moveable type north of the Alps, it now shares this claim to fame with Mewes' Concentus harmonici. ${ }^{4}$ Its position as the fountainhead of the transmission of polyphonic ode settings has also been revised. ${ }^{5}$ Likewise, its usability has been scrutinised: the number of mistakes in the musical text - including many that bear on performance, such as wrong clefs and missing flats - and the lack of text underlay in three of the four voices render it impractical as a basis for performance. ${ }^{6}$ These problems were rectified in the Harmonie, a second edition containing only Tritonius' settings of Horace, in a smaller format (quarto) and without the paratexts. Here the text underlay is given in every voice and most of the mistakes were corrected. ${ }^{7}$

Despite these blemishes to its reputation, the Melopoiae remains remarkable in many respects, in particular in the effect it had on its owners, readers and users. Its publication had a lasting influence, in two principal ways. From the perspective of the genre, Tritonius' settings resonated with publishers and composers. As Gundela Bobeth put it, it played a 'key role in the manifestation and continuation of humanist ode-settings' ${ }^{8}$ The humanistic appeal of the Melopoiae and its connection to Celtis meant that the book was prized for more than just the repertoire. It was widely collected and studied in a variety of contexts for centuries to come.

After briefly summarising the first aspect, this chapter will focus on this second point: the dissemination and use of the Melopoiae in the sixteenth century and beyond. A study of individual copies illustrates the varied roles this publication played in the libraries and lives of early modern users, partially reflecting the different uses intended by its makers, partially going beyond them. 


\section{Musical resonances of Tritonius' settings}

Tritonius' settings, first made widely available in the Melopoiae and Harmonie, had a lasting impact on composers, theorists and publishers. Immediate evidence of their impact is the re-publication or copying of Tritonius' pieces: after 1507 they also appeared in the Odarum Horatij Concentus, printed by Christian Egenolff in Frankfurt $(1532)^{9}$ and in the later, extended edition Geminae undeviginti odarum (1551). ${ }^{10}$ Even before Egenolff, Hans Judenkünig transcribed them for lute and published them in an appendix to his Utilis et compendiaria introductio (1523). ${ }^{11}$ The inclusion of these settings in a number of lute manuscripts further shows their role in instrumental music of the time. ${ }^{12}$ Other printers included individual settings in anthologies, ${ }^{13}$ and four of Tritonius' ode settings frequently appeared in books of music theory throughout the sixteenth century. ${ }^{14}$ At the same time several manuscripts, for example, from Irsee, Zwickau and Basel, also contain Tritonius' settings. ${ }^{15}$ These were, however, rarely direct copies from one specific source. Rather, they formed part of what Gundela Bobeth has called a 'creative reception of an ever-changing repertoire'. ${ }^{16}$

Further manifestations of this creative reception are the contrafacta and adaptations of Tritonius' settings. These include, for example, a manuscript in Munich containing one of Tritonius' tenors with Sebastian Brant's hymn Veritas summi patris. ${ }^{17}$ A much later example was printed in 1587, when Georg Rhon, cantor at the Latin school in Görlitz, edited a school song book which includes Tritonius' Iam satis terris, contrafacted with Melanchthon's hymn Dicimus grates. ${ }^{18}$ This is just one example of the use of metrical settings in hymn singing, a tradition that lasted well into the seventeenth century. ${ }^{19}$

Among the most prominent musical resonances of Tritonius' settings are the recompositions by other composers, most famously Ludwig Senfl, who reharmonised Tritonius' tenors. ${ }^{20}$ While the direct connection here to Tritonius is obvious, it is more difficult to assess his influence in the wider genre of metrical settings, which was to grow significantly in the two decades after the Melopoiae was published. It most prominently includes metrical settings by Wolfgang Grefinger, ${ }^{21}$ Paul Hofhaimer ${ }^{22}$ and Michael N. ${ }^{23}$ While these mostly have no direct musical link to Tritonius, the frequent use of the same Horatian texts is evidence of a tightly knit network of references. This 'complex intertextual web', as Grantley McDonald called it, might not have started with the publication of the Melopoiae, but the Augsburg publication undoubtedly played a crucial role in the acceleration and intensification of this process. ${ }^{24}$

In most of the mentioned cases it is unclear which edition of Tritonius' publications later publishers and composers used (the Melopoiae or Harmonie), or whether they were even working with a different strand of transmission. Gundela Bobeth has shown, for example, that Egenolff probably used the Harmonie. ${ }^{25}$ As this edition is both more accurate and userfriendly, it was a sensible choice by this famously pragmatic printer. The Harmonie thus evidently played an important role in the musical dissemination of Tritonius' work. What, then, was the position of the famous Melopoiae? A close examination of both the intentions of the makers and the evidence from early owners and users shows how the Melopoiae had a range of different functions in the early modern period.

\section{The many roles of the Melopoiae}

As with most authors, editors and publishers, the individuals behind the Melopoiae, particularly Konrad Celtis, had a number of different purposes and intended uses in mind. Some of these are made explicit in the paratexts, while others can be deduced. Scholars have 
interpreted the intention behind the Melopoiae mainly in two ways: panegyric or practical / didactic. The latter notion - that the Melopoiae was made predominantly for performance to aid students in learning classical metre - was long the dominant interpretation. Although acknowledging that the elaborate printing technique and paratexts made this book into more than a schoolbook, much previous scholarship emphasised the pedagogical use of collections of ode settings in general and the Melopoiae in particular. More recently, the former idea - that this work is a self-made homage to Celtis - has gained more importance. Birgit Lodes has concluded that ' $[t]$ he common reading of this publication as a primarily didactic publication thus needs to be revised' ${ }^{26}$ This is underlined by a closer evaluation of the Harmonie, more evidently a pedagogical publication, if not necessarily used in schools then at least for adult education. ${ }^{27}$ Some of the surviving copies, as, for example, the copy in the British Library, contain evidence of their use in a pedagogical context. ${ }^{28}$ The use of the Harmonie in a school context, combined with the smaller number of annotations of this kind in the Melopoiae has led to a perceived dichotomy, both in conception and use, between the Melopoiae as the panegyric, representative book on one hand, and the Harmonie as the schoolbook on the other. ${ }^{29}$ However, assigning the practical, educational use solely to the Harmonie is also misleading. Despite its admittedly impractical layout and many mistakes, the Melopoiae's didactic role should not be underestimated. In fact, considering these two intentions - the panegyric and practical / didactic - in more detail shows that they are not mutually exclusive, but in fact support each other.

\section{Panegyrics of Celtis}

The panegyric quality of this book is obvious in the way it celebrates its instigator, Konrad Celtis. Birgit Lodes has convincingly argued that Celtis conceptualised this publication as a way of installing himself as the German Horace, directly inspired by Apollo. ${ }^{30}$ On the title page, for example, he refers to his own 'Apollonian' verses: 'Celtis is said to have verses worthy of Apollo' ('Celtis apollineos fertur habere modos'). The woodcuts - Apollo on Parnassus and with the nine Muses - further underline this association, and are both closely linked to Celtis. ${ }^{31}$ Moreover, Celtis' own odes - modelled on those of Horace - would only appear in 1513, after Celtis' death in 1508. The Melopoiae may thus be seen as a preparatory publication, an important step in Celtis' self-fashioning as the German Horace, a project whose completion was however frustrated by the poet's death. ${ }^{32}$ In a table on fol. $1^{\mathrm{v}}$ of the Melopoiae Celtis placed the titles of his own poems next to the Horatian texts given in the book, as alternatives that could be sung to the same music. Throughout this book, as in his other publications, Celtis thus presents himself as the German 'arch-humanist'.

There is much to be said in favour of understanding the Melopoiae as a humanist publication and not primarily a book of music or music pedagogy. Its similarities with other humanist publications have been pointed out, in particular with Celtis' edition of the Ligurinus of Gunther von Pairis (1507) - both in regard to its material make-up as well as the ideas it disseminates - and place it in the context of Celtis' self-fashioning as a humanist. ${ }^{33}$

\section{Practical / didactic use}

Despite the rich humanistic soil from which it grew, the Melopoiae has traditionally been seen as predominantly a practical publication, one that would enable the singing of Horace's odes. This was to serve two different purposes: first, to help students appreciate the fine points of poetic diction and memorise classical metre. This didactic aim governed how the texts were selected as representatives of each of the nineteen lyric metres used by 
Horace. Second, this publication was intended to disseminate ancient practices of performing poetry, at least as Celtis imagined these practices to be.

Previous literature has usually placed the origins of the settings firmly into a pedagogical context, specifically Celtis' lectures on Horace at the University of Ingolstadt. In the preface to Senfl's collection of ode settings (1534), Simon Minervius writes that Tritonius, encouraged by Celtis,

composed harmoniae for the nineteen metrical species used by Horace, which he offered to his fellow students to sing together each day, like some kind of rallying-cry, at the end of the lectures on Horace which Celtis was giving at the time to a packed hall, modifying them with the sweet sound of the benevolent Muses. ${ }^{34}$

This narrative is plausible to the extent that Tritonius and Celtis overlapped at the University of Ingolstadt for a few months in 1497, ten years before the publication of the Melopoiae. ${ }^{35}$ While the idea for the ode settings might well have originated in Celtis' classroom, it is questionable whether the specific settings later published the Melopoiae were the ones sung at the lectures. If they were, then they were probably not performed in polyphonic versions. These harmonisations were likely only composed later; possibly, as has been suggested, in the context of the University of Vienna. ${ }^{36}$ Leaving the precise date of origin behind, Minervius clearly references a didactic purpose of this publication, specifically that of learning about Latin prosody. This is also referenced on the title page of the Melopoiae, when Celtis writes:

Excellent lover of the Muses, carefully observe the strophes, that is, the repetition of the verse forms, the elisions, the joining and marrying of the feet, as they relate to the emotion, the motion of the mind and the gestures of the body ('Optime musiphile strophos id est Repeticiones carminnm [sic] collisiones syllabarum coniugationes et connubia pedum pro affectu animi motu et gestu corporis dilligenter observa'). ${ }^{37}$

The other didactic reason for Celtis to foster the performance of the odes was his wish to resurrect the ancient way of performing poetry, a prominent idea among humanists in Italy and increasingly also in Germany. They felt that this was one of the (for music rather rare) instances in which ancient practices could be resurrected. Ode settings were, in the words of Johannes Cochlaeus, a 'representation of antiquity' ('antiquitatis simulacrum'). ${ }^{38}$ The humanists argued that to sing, rather than purely recite poems, was what the ancient poets themselves had done and intended. As Horace wrote, 'I speak words worthy of being joined to the sound of strings' ('verba loquor socianda chordis'). ${ }^{39}$ Grantley McDonald has shown how this echoed the Neoplatonic view of poetics, as understood by Celtis and others. ${ }^{40}$ On the title page of the Melopoiae, Celtis explicitly refers to this when he writes how fortunate the Germans are that they can now finally sing in the way the ancient Greeks and Romans did: 'How lucky you are, o land of Germany, which now sings poems in the manner of Greece and Rome' ('felix nunc o Germanica tellus Que graio \& lacio carmina more canit'). ${ }^{41}$

In early modern Europe there was little knowledge about how exactly the ancients sang Latin poetry, and different approaches to resurrecting this practice co-existed. In Italy, singing extempore Latin poetry, accompanied by the lira da braccio or lute, became popular in the fifteenth century. Yet, due to the spontaneous nature of this practice, hardly any written sources from the fifteenth century survive. ${ }^{42}$ North of the Alps, Celtis and his contemporaries approached the topic mainly through the metrical settings. Celtis probably did not believe 
that ancient poetry was sung in four voices in the way we find Tritonius' ode settings in the Melopoiae. However, he does not address this discrepancy in any way in the publication. What was important to Celtis, it seems, is that they were sung, not merely read. As with other cases, what we find here is an early modern reinterpretation of an ancient practice rather than an actual resurrection with any claim to authenticity. This stands somewhat in contrast to the humanists' rhetoric: that they, after the ignorance of the Middle Ages, were finally reading the classics as they were intended, directly and pure. Textual scholars, however, have shown that in reality that was rarely the case. The humanists did not encounter the classics in an unmediated fashion. As Anthony Grafton writes, 'humanistic manuscripts and printed books were not the revival of something old, but the invention of something new ${ }^{\prime}{ }^{43}$

The practical difficulties of using the Melopoiae may have been a serious impediment to its use for practical or didactic purposes, but made little difference for its utility in disseminating the idea of singing poetry. The Harmonie, or any one of the many later publications that follow in its footsteps in format, text underlay and so on, would have been a more obvious choice for such contexts. However, for the second aspect - the dissemination of the idea of ancient sung poetry - the awkward layout and mistakes mattered much less. Hence, even if the Melopoiae was not used directly in performance, it could be used to educate (oneself or others) about this practice; to this extent it should still be considered a pedagogical publication. In this it is similar to the many textbooks for use at school or university, which appeared in German-speaking lands in the sixteenth century and beyond. They were not intended for performance. In fact, in most cases they do not contain entire pieces, but only extracts. But they taught students about music, and how to sing. In that sense, the Melopoiae also educates about a practice which Celtis believed worthy of resurrection.

At the same time, this didactic approach, the spreading of this idea, also serves the earlier function of the Melopoiae, that of the panegyric of Celtis. By introducing this new, yet ostensibly ancient practice, Celtis manifests his position as Germany's arch-humanist. In good humanist fashion, he aimed to resurrect a technique and thus to enrich his contemporaries' experience of the ancient texts. From this perspective, the 'didactic' and 'panegyric' purpose are not mutually exclusive, but in fact support each other. With the introduction of this practice, Celtis also contributed to the dissemination and appreciation of Horatian poetry. Of course, the Melopoiae include Horatian texts, although in selective and truncated form. More importantly, however, it gives individuals a way to enjoy these texts in a new, seemingly authentic form. ${ }^{44}$

\section{Christian hymns}

One further intention behind the publication of the Melopoiae has recently been highlighted: namely, its role in the context of efforts to revive Christian singing. Andrea Horz has convincingly argued just how involved some early German humanists, including Celtis, were in resurrecting the singing and composition of hymns, specifically, the composition of new hymns for various saints. ${ }^{45}$ At the end of the Melopoiae is a catalogue of church hymns listed by metre, which could be sung to the settings presented in this volume. ${ }^{46}$ This is also a precursor to a range of four-voice hymn settings according to metrical rules. Once again the Melopoiae might not have been directly useable to sing these hymns to metre - after all, only the titles are given. Readers would have had to know the hymns by heart to sing them, which is, of course, a possibility, or consult another book containing these texts. However, its merit predominantly lies in introducing this idea, again serving a didactic, if not directly practical use. 
To summarise, this was both a humanist as well as a didactic book, with the didactic element cementing its humanist nature. The 'resurrection' of the ancient tradition of singing poetry and the metric singing of hymns serve both as ways to underline the profoundly humanistic character of the book - and by extension the cultural mission of its instigator, Celtis - as well as a didactic purpose. A closer examination of surviving copies of the Melopoiae shows how these intentions are reflected in the ways in which early readers interacted with their copies of the Melopoiae, in ways that also went beyond the immediate intentions of its makers.

\section{Owning and reading the Melopoiae}

While some work on individual copies of this exceptional publication has been done ${ }^{47}$ the overall impression remains that 'the often referenced radiance and importance of the ode repertoire first published in the Melopoiae stands in an astonishing mismatch to how much we actually know about details of its reception and influence', as Gundela Bobeth put it. ${ }^{48}$ Thus, a closer look at surviving copies enriches our understanding of its reception. Two main questions guide this quest. First, who bought and owned the Melopoiae? Second, how did they use their copies? The 'use of a book' in this context is understood rather broadly. It can include its uses in performance, as reading material, basis for study or as an item worthy of collection..$^{49}$ Consequently, ways of asserting that use are equally diverse. There are the obvious, delightful signs revealing the presence of early users, such as marginal annotations and corrections, as well as the less obvious ones, in particular the examination of the books with which they were bound, as a basis for understanding the context in which they were used or collected.

There are in fact, an astonishing twenty-five surviving copies (see Appendix 4.1). This number is especially high if compared to other music publications of the time: Mewes' Concentus harmonici, published in Basel in the same year, survives in only one complete copy, and an additional altus partbook. ${ }^{50}$ One of Oeglin's songbooks exists is three known copies, another in only one. ${ }^{51}$ Often a negative correlation between survival and use has been postulated: books that were heavily used, particularly music books used as performance material, often did not survive. Hence a high survival rate may signify that the book was not much used. To some extent this axiom can also be applied to the Melopoiae: it was, after all, not particularly useful as performance material. This particular view, however, neglects uses beyond performance. Moreover, other factors also contributed to this particularly high survival rate. Most important is its format. Books in folio format survive more often than smaller ones. ${ }^{52}$ Additionally, big books were often made as impressive presentation items that would be highly valued. But even if they were used in performance, the format of a book had a directly correlation with its likelihood of survival: bigger books are harder to lose. Another example of this is the famous Liber selectarum cantionum, the only other book of polyphonic music printed in folio format in the German-speaking areas during the first decades of the sixteenth century, which survives in twenty-two copies. ${ }^{53}$ In this case, size does matter.

The celebrated woodcuts also added a further advantage for the Melopoiae's survival chances. Although not by Dürer himself (as believed for some time), but rather by an unidentified 'Celtis-Meister', they were valued items, as can also be seen by their preservation separate from the rest of the publication: in at least two of the surviving copies of the $\mathrm{Me}$ lopoiae the woodcuts have been removed. ${ }^{54}$ On the other hand we know of two instances where fragments (with at least one woodcut) survive separately from the rest of the book: one is bound at the end of a copy of Celtis' Ligurinus (also printed by Oeglin in 1507), now 
in the Austrian National Library. ${ }^{55}$ In addition to both woodcuts from the Melopoiae individually (probably printed on single sheets) it also contains folios 1 and 10 of the Melopoiae: that is, the title page with the 'Crater Bachi', and the final folio. According to an inscription on the final page, the volume formerly belonged to the Augustine monastery of St. Dorothy in Vienna, which was dissolved in 1786 and its library dispersed. ${ }^{56}$ The same two folios (A1 and A10) are also bound with a copy of Gaffurius' Practica musicae in the University Library of Salzburg. ${ }^{57}$ With its celebrated woodcuts and large format, impractical for use as performance material in schools, the Melopoiae had a good chance of survival; the high number of surviving sources is thus not surprising. The context in which these copies were bought, given away, collected and used, however, shows a range of ways in which readers might engage with it.

\section{Book collectors}

There were (and are) several reasons to collect this book: for example, as part of a broad, universal library, to represent a specific musical genre, or to commemorate an important step in the development of (music) printing. As for universal collectors, it comes as no surprise that the bibliophile omnivore, Ferdinand Columbus, purchased a copy of the $\mathrm{Me}$ lopoiae at Nuremberg in December $1521 .{ }^{58}$ Columbus, who was interested in basically every early printed book, probably did not seek out the Melopoiae for any particular reason, but simply acquired it as one item in his extensive collection.

Another famous bibliophile who assembled one of the largest private collections of the later fifteenth and early sixteenth century was the Nuremberg physician Hartmann Schedel. Of his library, 370 manuscripts and 460 individual printed titles survive in the Bayerische Staatsbibliothek in Munich. ${ }^{59}$ Among them is his copy of the Melopoiae, easily identifiable as one of his books by the distinctive red and blue markings and foliation (see Figure 4.1). Schedel's book collecting, although broad in its approach, was governed by his specific interests. Apart from medical works, he keenly collected and copied antique texts, contemporary writers, and books on European history and geography. As a student in Padua in the 1460s he had come into contact with Italian humanist writers, and throughout his life he keenly collected their works, often specifically requesting new Italian publications or manuscripts from book agents. ${ }^{60}$ At the same time he was closely involved with German humanists, including Celtis, and shared their enthusiasm for showcasing the role and status of Germany in contemporary culture, an endeavour that led to his famous Weltchronik. ${ }^{61}$ The two catalogues of his library reflect these interests. ${ }^{62}$

Absent from Schedel's particular interests or his understanding of the studia humanitas is music. This might seem at odds with the fame of his (only) music manuscript, the socalled Schedelsches Liederbuch. However, Martin Kirnbauer has convincingly shown how this manuscript was part of Schedel's wider interest in copying texts (Greek, Latin, diagrams) and not a basis for or record of performance or even a sign of a particular interest in music. ${ }^{63}$ The few known items of musical interest in his library consist of a copy of Guido of Arezzo and a volume of music theory, both listed under the mathematics section of his catalogue ${ }^{64}$ Furthermore, his collection included a few items of musical interest in the context of the veneration of St. Sebald (patron saint of Nuremberg, Schedel's home for most of his life) and a music textbook connected to the reform of Nuremberg's schools. ${ }^{65}$

To these known items, a few more publications containing musical notation can be added, which illustrate Schedel's interest in humanist plays with music. The first is a copy of the Ludus Dianae, Celtis' panegyric play written for Maximilian, which contains two homophonic choruses for four voices and is - with its association with Celtis, German humanism and homophonic musical settings - a close cousin of the Melopoiae. ${ }^{66}$ Similarly, 


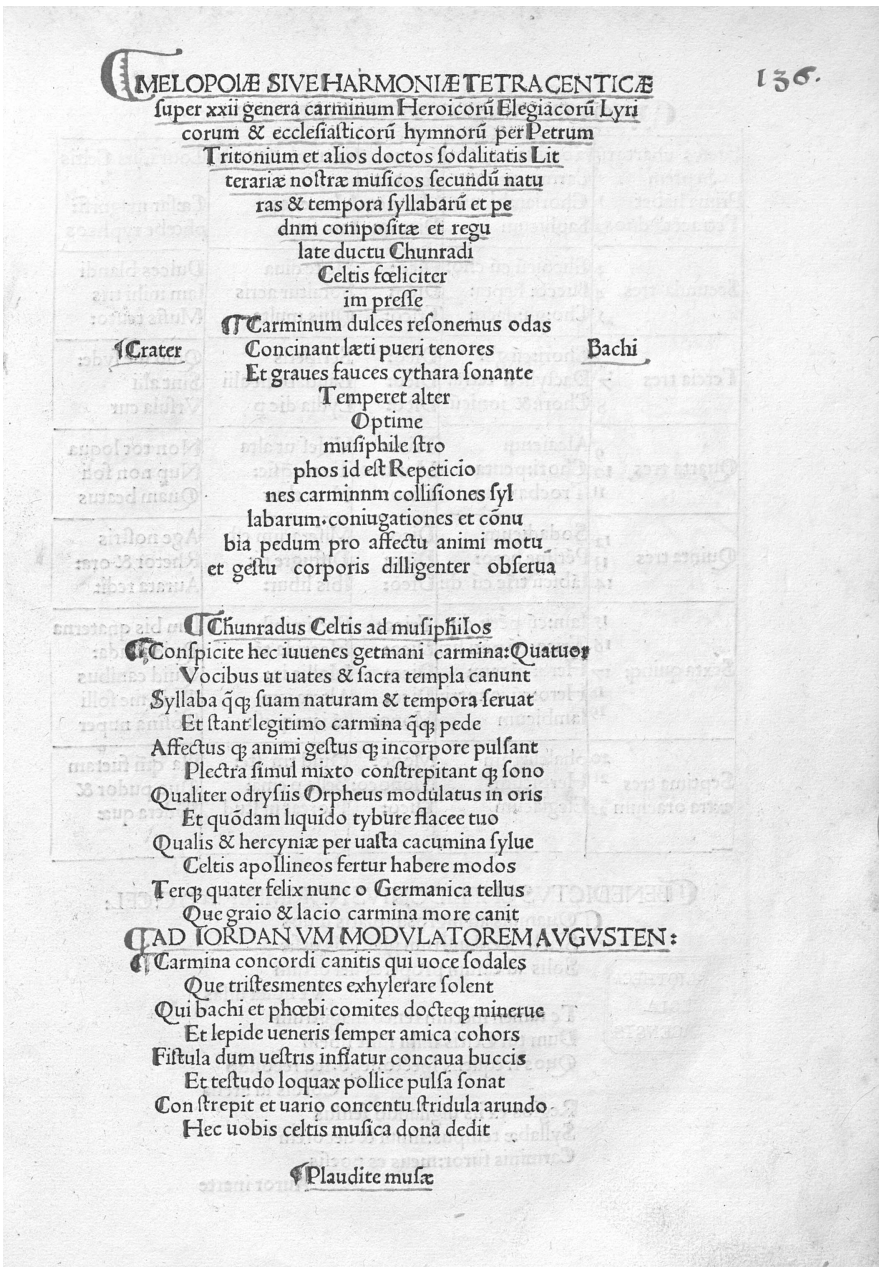

Figure 4.1 Konrad Celtis and Petrus Tritonius, Melopoiae (Augsburg: Erhard Oeglin, 1507), vdm 55, fol. $1^{\mathrm{r}}$.

Source: Munich, Bayerische Staatsbibliothek, Rar. 291.

Schedel's library also contains two different editions of one of the most famous and most frequently printed early modern plays, Johannes Reuchlin's Scaenica progymnasmata. Both editions, printed in Basel 1498 and Tübingen 1511 respectively, contain four monophonic choruses with notation. ${ }^{67}$ A further chorus for four voices is part of the Rhythmus die divi Martini, a 'rhythmical song performed on St Martin's day' by the Italian Antonio Urceo Codro. Schedel owned a German edition of this popular pamphlet; interestingly, only the German editions, not the Italian ones, contain the music in addition to the text. ${ }^{68}$ Schedel presumably purchased - or was presented with - the Melopoiae as part of this humanist endeavour by a convinced humanist, but was by no means a musically minded collector. ${ }^{69}$

\section{Honouring Celtis}

Schedel's copy of the Melopoiae could also be seen as evidence that contemporary collectors honoured the association of this publication with Celtis. More specifically, Birgit Lodes has 
pointed to the copy in Wolfenbüttel, which reflects the Celtis panegyric in the way it is collected, including some woodcuts of or connected to Celtis, the Melopoiae, the Ligurinus and a lamentation on Celtis' death. ${ }^{70}$ Similarly, the copy in Lund is also bound with the Ligurinus, in a beautiful wooden binding. ${ }^{71}$ According to an inscription on the title page it belonged to Celtis' pupil Gregor Nitsch. In fact, Nitsch claims, this volume was presented to him by Celtis himself before the poet's death. ${ }^{72}$

The copy in Freiburg University Library contains another reference to Celtis: on fol. $1^{\mathrm{r}}$ an early user has entered the words 'Nota: Haec stropha. Carminum dulces etc. Desumpta est ex ode ultima lib. I ad Phoebum et Musam Suam. Incipit: Quid gra[ves] nos mentis mihi fers Labore'. This user has correctly identified that the lines from the title page of the Melopoiae ('Carminum dulces resonemus odas/ Concinant laeti pueri tenores/ Et graves fauces cythara sonante, temperet alter') are exactly repeated in one of Celtis' own odes. They appear in 'Ad Phoebum et Musam suam', the final poem in the first book of Celtis' odes (1513), exactly as the scribe indicates. Moreover, this particular ode speaks to Phoebus Apollo, who is depicted on the next page. ${ }^{73}$

\section{Humanist learning - The Melopoiae as a didactic text}

Several surviving copies attest to the Melopoiae's place in humanist learning. The copy in the University Library of Wrocław is bound with six other items. ${ }^{74}$ The sixteenth-century leather binding and the consecutive numbering of all items in brown ink suggest that they were bound together for an early (probably sixteenth-century) owner - maybe the person who has identified himself on the title page of the first item as 'Henricus Cohelinus [?]'. ${ }^{75}$ Bound together are:

1. Johannes de Sacrobosco, Sphaera mundi Cum commentariis, Venice: Simon Bevilaqua, 23 Oct. 1499 (USTC 993974).

2. Georg von Peuerbach, Theoricae novae planetarum, Nuremberg: Johann Müller of Königsberg (Regiomontanus), 1474 (USTC 748363).

3. a) Agostino Nifo, De nostrarum calamitatum causis liber, Venice: Boneto Locatelli for the heirs of Ottaviano I Scoto, 1505 (USTC 844632).

b) Agostino Nifo, Averroys de mixtione defensio, Venice: Boneto Locatelli for the heirs of Ottaviano I Scoto, 1505 (USTC 844628).

c) Agostino Nifo, De diebus criticis seu decretoriis aureus liber: nuper editus et maxima cum diligentia impressus, Venice: Giacomo Penzio for Alessandro Calcedonio, 1504 (USTC 844630).

4. Johannes Stöffler, Germani tabulae astronomicae, Tübingen: Thomas Anshelm, 1514 (USTC 669288).

5. Melopoiae sive harmoniae tetracenticae, Augsburg: Erhard Oeglin, 1507 (vdm 55).

6. Franchinus Gaffurius, Practica musicae utriusque cantus, Brescia: Bernardino Misinta, for Angelo Britannico, 1502 (USTC 831340).

In short, the Melopoiae here is preceded by an astronomical bestseller from the thirteenth century (produced in more than 300 editions and here in a version with commentary by leading scholars of the early sixteenth century) and a work on Ptolemaic astronomy by one of these commentators, Austrian astronomer Georg von Peuerbach. Next are three short titles by the Italian philosopher Agostino Nifo, and a volume of astronomic tables by the German mathematician and astronomer Johannes Stöffler. After that the Melopoiae is followed by another early modern bestseller, Gaffurius' Practica musica. 
One common denominator of all these volumes is clearly their format. It could be supposed that these books were purely bound together on this basis. However, the folio format was rather common for text publications, unlike music publications of the time. Most of Agostino Nifo's books, for example, were printed in folio. ${ }^{76}$ Thus we can assume that the collector of these books had a range of folio books to choose from and selected them not purely on the basis of their format. Moreover, the coherence around the theme of astronomy for many of the titles suggests a purposeful selection. We might surmise then that this collector thought that Melopoiae belonged among his books about astronomy, cosmology and, with Gaffurius, music theory. This collected volume thus represents humanistic scholarship with a particular interest in astronomy.

Another example of the Melopoiae in a collection of early sixteenth-century learning is the copy now in the Stiftsbibliothek in St. Gallen. ${ }^{77}$ The specific selection of themes, however, is rather different to the one just discussed. The St. Gallen copy is bound with nine items, all printed around $1500 .{ }^{78}$ On the title page of the first item the words 'Liber S. Galli' have been entered; later, on fol. A2 it reads: 'Hunc librum aere proprio sibi frater Melchior Ratzenhoffer comparavit aere [?] anno domini 1575'. This date, and the presence of sixteenth-century annotations in all titles of the compound volume has led Sabine Bachofner to suggest that the entire volume was already bound together in the sixteenth century, and became part of the library in St. Gallen early. The Melopoiae here finds itself in the illustrious company of books on ancient philosophy, poetry, and law, Porphyry's introduction to Aristotle's Categories (a standard textbook on logic), Boethius' Consolation of Philosophy, Cicero's De officiis and Horace's Satires, all in editions from the early sixteenth century. It was thus collected in the context of interest in ancient philosophical writing and poetry - a perfect fit for Horatian odes in a publication trying to resurrect an ancient musical tradition. There is furthermore evidence of the ways in which an early reader used the Melopoiae: on fol. $9^{\mathrm{v}}$ (the overview of Christian hymns) he entered some grid diagrams to explain the metre as well as some further explanations (see Figure 4.2). Such grid schemata were another popular way to illustrate Latin metre and were used by Celtis himself in his Ars versificandi et carminum, first published in $1486 .^{79}$ This copy thus exemplifies how the Melopoiae was both collected and read in a learned context, in particular here with a view of learning Latin metre. A further example of learned collecting is the copy of the Melopoiae now in the Stiftsbibliothek Zwettl, which was bound with a Latin translation of Diogenes Laertius' Lives and Opinions of Eminent Philosophers, and Aulus Gellius' Attic Nights, his miscellany with notes on a range of subjects. ${ }^{80}$

\section{Resurrecting the 'authentic way of singing'}

Evidence that Celtis' mission to resurrect the 'authentic way of singing' interested an early reader might be seen in the copy of the Melopoiae now held in the University Library in Munich. ${ }^{81}$ The copy is bound on its own and has a moderate amount of underlining and some marginal annotations. These represent three different ways of engaging with the printed book.

First, annotations to help to identify the publication. They include, for example, the addition of the date '1507' on the title page, information otherwise only given in the colophon. Similarly, the early user has underlined the part of the colophon identifying the book's printer and publisher. Second, the reader underlined sections to aid the navigation on the page, for example, the headings in the table on fol. $1^{v}$, which are not clearly 


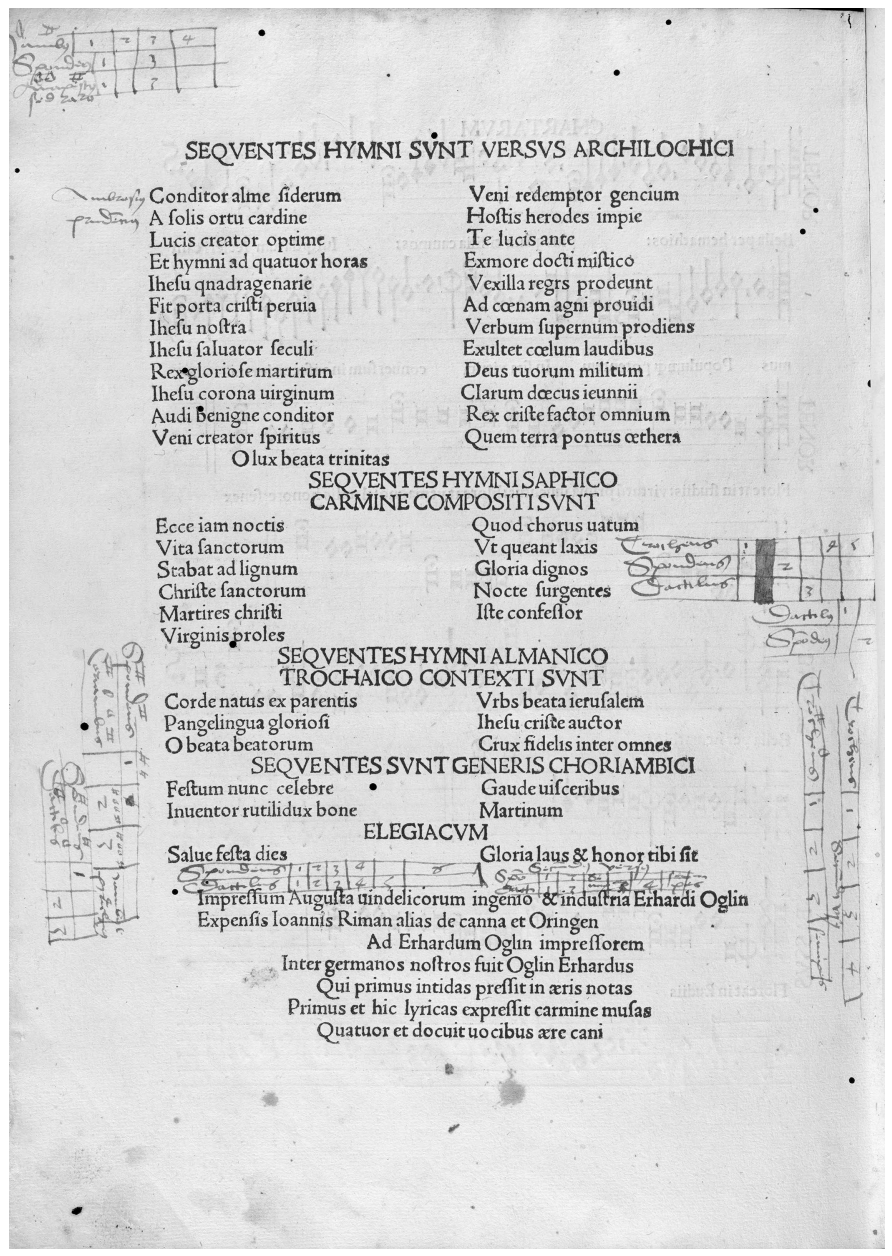

Figure 4.2 Konrad Celtis and Petrus Tritonius, Melopoiae (Augsburg: Erhard Oeglin, 1507), vdm 55, fol. $9^{\mathrm{v}}$.

Source: St. Gallen, Stiftsbibliothek Ink. 379.

distinguished typographically. Similarly, next to the woodcut of Apollo on Parnassus, an early user has entered the names of the items depicted, mostly copying the captions already given in the woodcut. Rather than identifying them, it seems he was learning them through scribal repetition.

Finally, the reader underlined specific words or phrases, which seem to indicate his specific interests while reading this publication: On the title page, for example, he first underlines the words 'Excellent reader ...' ('Optime musiphile strophos ...') and thus the section which explains the novelty of this approach. Later the sentence 'Three and four times happy, o German land, which now sings poems in the manner of Greece and Rome' ('Terque quater felix nunc o Germanice tellus/ Que graio \& lacio carmina more canit') is also marked. This sentence also refers to Celtis' intention of resurrecting the 'authentic' way of performing Latin poetry, to his humanist programme and part of its self-identification, ideals which apparently resonated with this reader. ${ }^{82}$ 


\section{Musical uses}

Finally, several surviving copies show evidence that they were used for the performance of the ode settings, or to collect a repertoire of such settings. One of the two copies now held in the British Library was used in an attempt to perform some of the musical settings, or at least to understand how they could be performed.$^{83}$ On the first opening with music, an early user has entered the text of Iam satis terris in the discantus voice, further aided by hyphens to divide the notes according to the text (see Figure 4.3). Quickly, it seems, he realised the difficulty of this endeavour and gave up, since none of the other pages have similar markings. ${ }^{84}$

Next, the copy now held in the University Library in Basel gives evidence of this publication's role in the collection, preservation and probably performance of the quantitative verse setting. ${ }^{85}$ It once belonged to Christoffel Wyssgerber (Christopherus Alutarius), a teacher from Basel and local humanist. At the end of his copy of the Melopoiae he added a number of folios on which he entered further settings and arrangements of those contained in the printed book. These additional leaves, now kept separately as manuscript F II 35, offer a fascinating window into the reception of the repertoire. ${ }^{86}$ Wyssgerber's manuscript additions have been dated to around 1534 and the reworkings and addition of pieces, many of which were intended for the performance in school plays, show an active engagement with the repertoire twenty-five years after it first appeared in print. Apart from the additional pages, the printed book itself also shows signs of use: on folio $3^{\mathrm{v}}$, an early reader (probably Wyssgerber) has entered the correct tenor voice of Sic te diva potens, probably copied from the Harmonie.

The copy in the Newberry library in Chicago is of interest for two additions, one textual and one musical. ${ }^{87}$ The latter falls into the same category of use as the copy just described. On the lowest two empty staves on folios $3^{\mathrm{v}}-4^{\mathrm{r}}$, the second opening that contains music, an early user entered a four-voice quantitative setting of Ovid's Hanc tua Penelope (see Figures 4.4 and 4.5). This text - a fictional love letter by Penelope to Ulysses - was, as far as we are aware, not set to music by Tritonius, though others, including Ludwig Senfl, ${ }^{88}$ Benedict

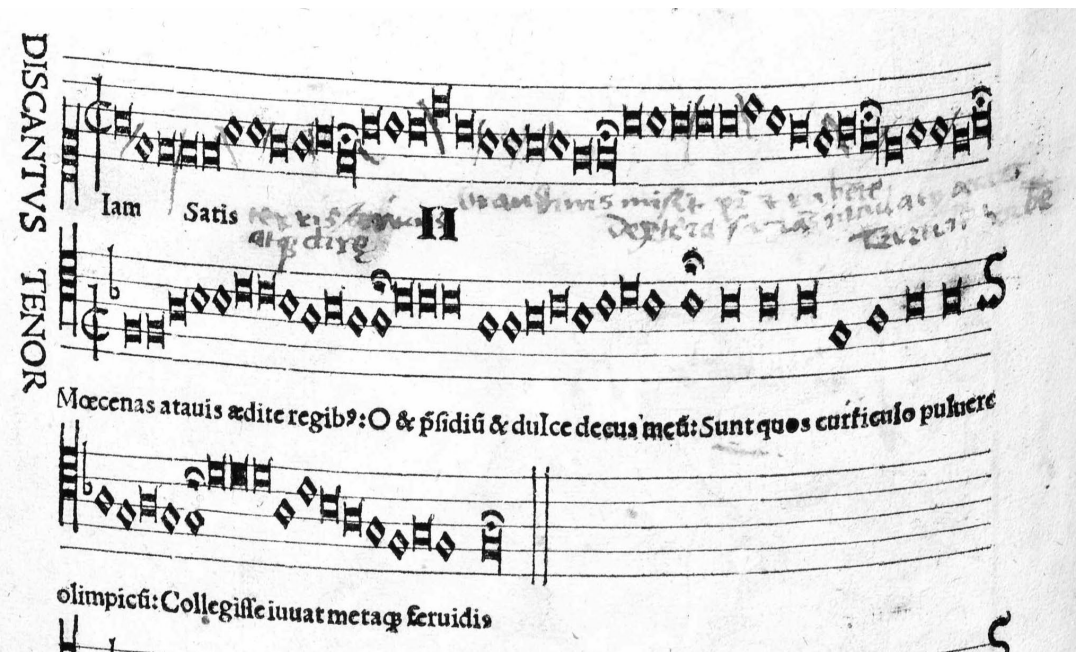

Figure 4.3 Konrad Celtis and Petrus Tritonius, Melopoiae (Augsburg: Erhard Oeglin, 1507), vdm 55, fol. $2^{\mathrm{v}}$.

Source: London, British Library, Hirsch III 1130. 


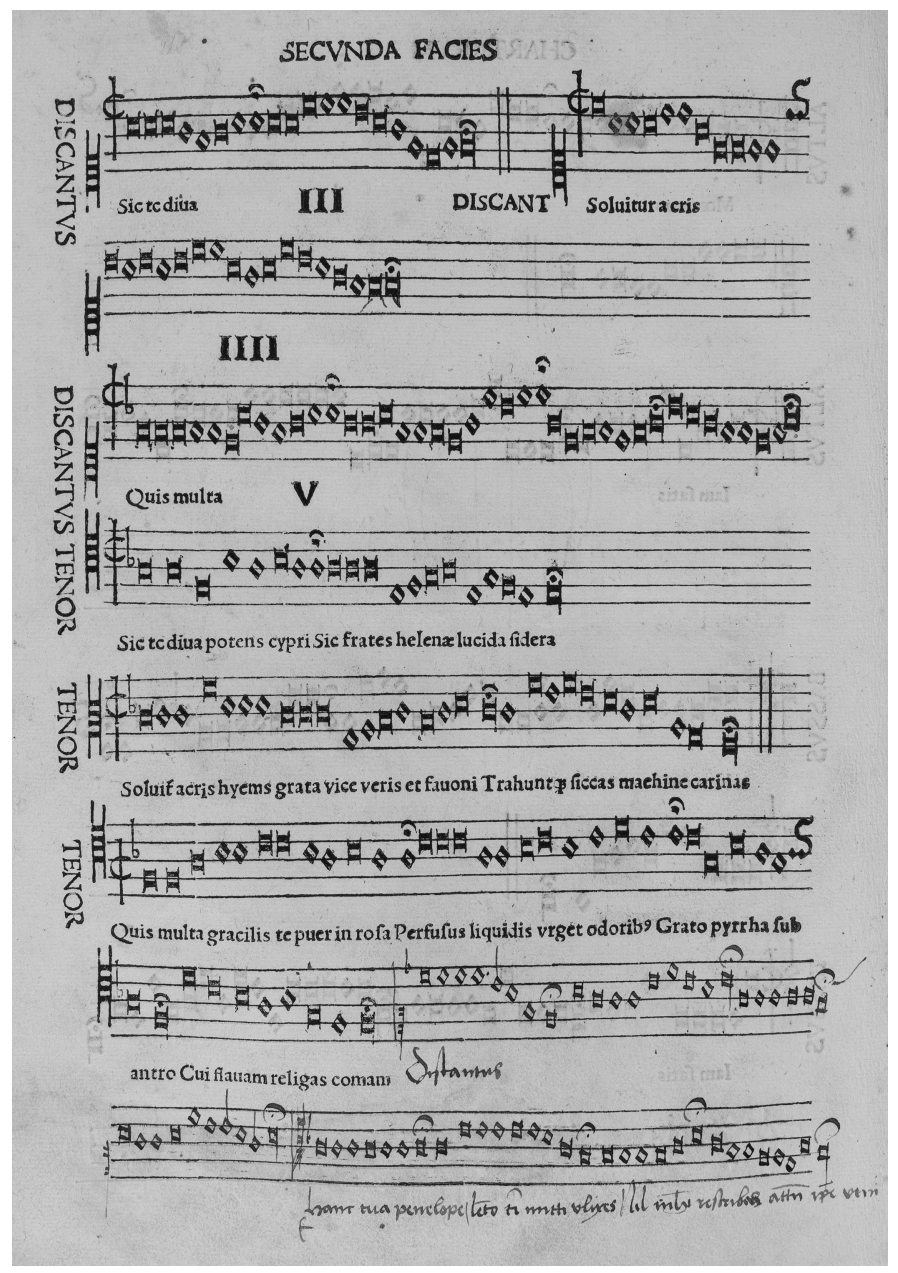

Figure 4.4 Konrad Celtis and Petrus Tritonius, Melopoiae (Augsburg: Erhard Oeglin, 1507), vdm 55, fol. $3^{\mathrm{v}}$.

Source: Chicago, The Newberry Library, VAULT Case VM 1490.T83m.

Ducis,${ }^{89}$ Johannes Heugel,,${ }^{90}$ and Michael N., ${ }^{91}$ did. In this rather unusual setting, the tenor moves very little, and then mainly in conjunct motion, while the other voices have some large leaps. This setting does not overlap with any of these mentioned settings. This particular opening in the Melopoiae was an obvious place to enter additional music, as it has the most free space on the printed staves. The scribe followed the layout of the printed book and entered the tenor and discantus on the left, the altus and bassus on the right side of the opening. Whether it was copied from another book or composed by the scribe, it is in any case a good example of the way readers could use a printed book as a starting point, enlarging it with related content. ${ }^{92}$

A second addition to this copy is of particular interest. Entered in the empty space next to the tenor of Iam satis on fol. $2^{\mathrm{v}}$ is a ten-strophe rhymed text starting 'Vive vive mi Luthere' (see Figure 4.6), a song celebrating Luther's burning of the papal bull of excommunication on 10 December 1520 in Wittenberg. The text (see transcription in Appendix 4.2), attributed 


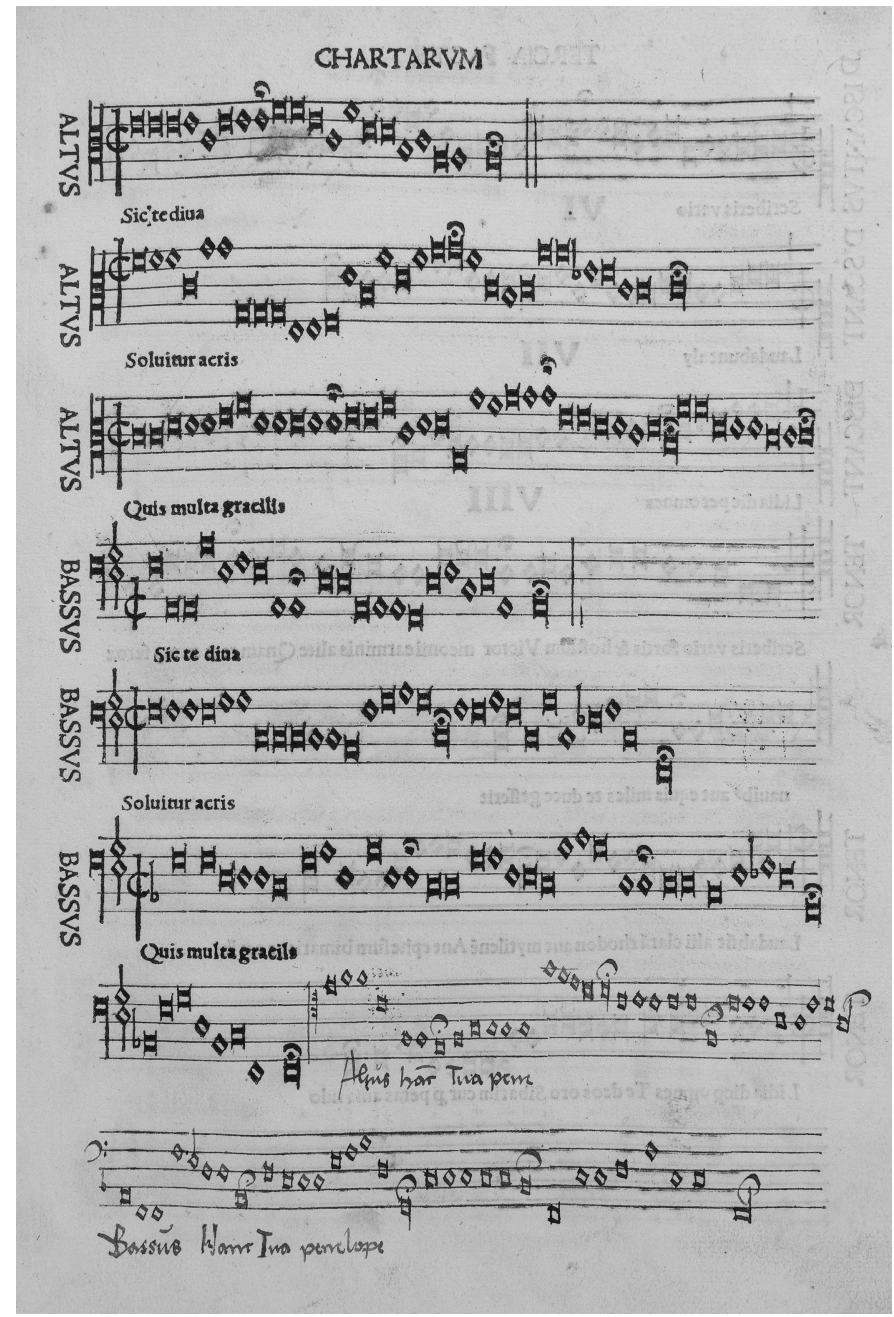

Figure 4.5 Konrad Celtis and Petrus Tritonius, Melopoiae (Augsburg: Erhard Oeglin, 1507), vdm 55, fol. $4^{\mathrm{r}}$.

Source: Chicago, The Newberry Library, VAULT Case VM 1490.T83m.

to the reformer Urbanus Rhegius, celebrates this event, ending each three-line strophe with a joyful refrain, 'Io, Io' ${ }^{93}$. This text survives in several different versions. Presumably the earliest is a printed single sheet surviving in Berlin. ${ }^{94}$ Many decades later, in 1591, Andreas Stangwald included it in his second edition of Luther's table talk, in a shorter and altered version..$^{95}$ Yet another version is also found in the Confessio Augustana oratio historica - an account of the history of Protestantism - in a form closer to that on the single sheet than Stangwald's text. ${ }^{96}$ This last-mentioned source most closely resembles the text entered in the Newberry copy of the Melopoiae. However, the differences are too significant to suggest it was copied from this particular publication; moreover, the handwriting in this copy appears to be from the earlier sixteenth century. ${ }^{97}$ In the Newberry copy, the scribe also only gives the text, but no explanatory details, title or the initials of the author (V[rbanus]. $\mathrm{R}$ [hegius].), as included, for example, on the single-sheet publication. Evidently a number 


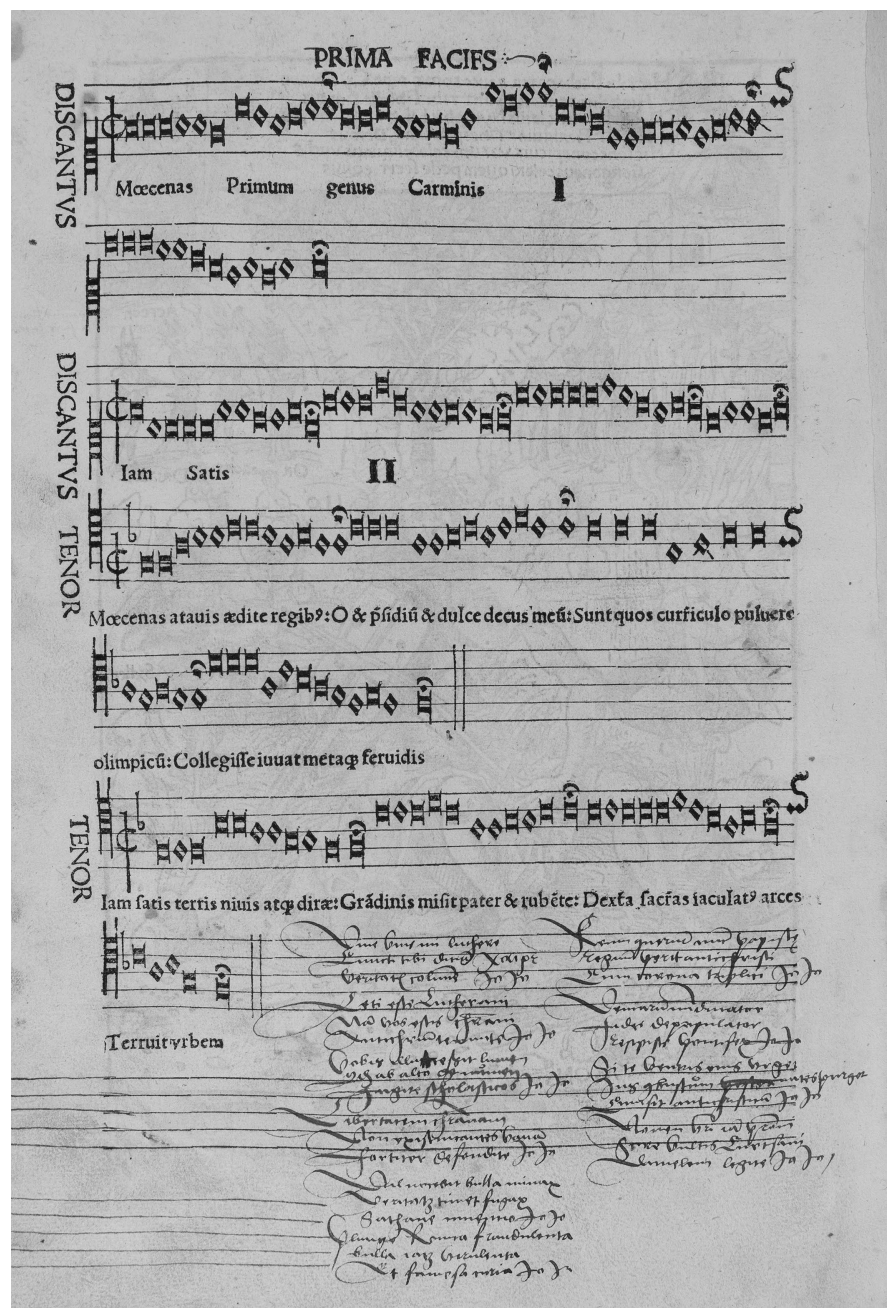

Figure 4.6 Konrad Celtis and Petrus Tritonius, Melopoiae (Augsburg: Erhard Oeglin, 1507), vdm 55, fol. $2^{\mathrm{v}}$.

Source: Chicago, The Newberry Library, VAULT Case VM 1490.T83m.

of different versions of this text were in circulation throughout the sixteenth century. Its inclusion in the Melopoiae shows that this copy was apparently still in use after December 1520, when Luther burned the bull. It also suggests that this copy of the Melopoiae might have been used within a pro-Lutheran context, or at least in conjunction with pro-Lutheran publications which might have contained this text.

\section{Conclusion and later history}

There were many reasons to collect and use the Melopoiae, some of which reflected the diverse intentions of its makers, particularly Konrad Celtis. It was collected as part of universal libraries and often had a place in compendia focussed on humanist learning, some specifically in connection to Celtis. At the same time, some early owners did indeed use it 
to learn Latin metres. Others were, it seems, particularly interested in the idea that it would help to resurrect an ancient way of reciting poetry. For others, then, it was a starting point of an active engagement with the genre of metrical settings.

This diversity of approaches continued well beyond the sixteenth century. A second, otherwise rather 'clean' copy of the Melopoiae, now held in the British Library, gives evidence that the Melopoiae was desirable for universal collectors for many centuries to come: it was bought by the physician and keen book collector Georg Kloss in the early nineteenth century. ${ }^{98}$ The copy now held in Rochester, NY, on the other hand, was once owned by Alfred Henry Littleton, a music publisher who lived at the turn of the twentieth century, who compiled a library to facilitate his work on the history of music printing. ${ }^{99}$ Clearly the Melopoiae's status as one of the first examples of multiple-impression printing north of the Alps made it an attractive item for Littleton. A different type of nineteenth-century collector was Georg Poelchau - pupil of Telemann, owner of the largest private collection of Bach manuscripts, and avid collector of all kinds of books of music. Among his rich collection of more than 2,600 items, now held in the Staatsbibliothek Berlin, is another copy of the Melopoiae, which bears no other signs of use or ownership. This book was collected then as part of the library of a musician and bibliophile with a specific interest in music - rather the opposite of Schedel a few hundred years earlier. ${ }^{100}$ This wide range of ambitions and potential uses - offering something for everyone, it seems - also keeps this book in its central position in musicological scholarship.

\section{Appendix 4.1 Extant copies of the Melopoiae}

\begin{tabular}{|c|c|c|}
\hline Location & Shelfmark & Condition \\
\hline A-Su (Salzburg, Universitätsbibliothek) & $\begin{array}{l}\text { F II } 475 \\
\text { (angebunden) }\end{array}$ & Only fols. [1] and [10] \\
\hline $\begin{array}{l}\text { A-Wn (Wien, Österreichische } \\
\text { Nationalbibliothek) }\end{array}$ & SA.76.A.3 & Complete \\
\hline $\begin{array}{l}\text { A-Wn (Wien, Österreichische } \\
\text { Nationalbibliothek) }\end{array}$ & 53.C.26 & Only fols. [1] and [10] \\
\hline $\begin{array}{l}\text { A-Z (Zwettl, Zisterzienserstift, Bibliothek } \\
\text { und Musikarchiv) }\end{array}$ & StiBZ Inc. I/138 & Complete \\
\hline $\begin{array}{l}\text { B-Br (Brussels, Bibliothèque Royale de } \\
\text { Belgique) }\end{array}$ & $\begin{array}{l}\text { Fétis } 2.207 \text { C } \\
\text { (Réserve précieuse) }\end{array}$ & Complete \\
\hline $\begin{array}{l}\text { CH-Bu (Basel, Öffentliche Bibliothek der } \\
\text { Universität Basel) }\end{array}$ & kk I 27 & $\begin{array}{l}\text { The two woodcuts have been } \\
\text { cut out, with resulting loss of } \\
\text { musical text. }\end{array}$ \\
\hline CH-SGs (St. Gallen, Stiftsbibliothek) & Ink. 397 & Lacks pp. 9-12 \\
\hline $\begin{array}{l}\text { D-As (Augsburg, Staats- und } \\
\text { Stadtbibliothek) }\end{array}$ & Cim 442 Tonk 28 & Complete \\
\hline $\begin{array}{l}\text { D-B (Berlin, Staatsbibliothek zu } \\
\text { Berlin - Preußischer Kulturbesitz, } \\
\text { Musikabteilung) }\end{array}$ & Mus.ant.pract. T 150 & $\begin{array}{l}\text { Final folio missing; photos from } \\
\text { D-Mbs Rar. } 291\end{array}$ \\
\hline $\begin{array}{l}\text { D-FRu (Freiburg im Breisgau, } \\
\text { Universitätsbibliothek) }\end{array}$ & Rara F 9222 & Complete \\
\hline $\begin{array}{l}\text { D-Mbs (München, Bayerische } \\
\text { Staatsbibliothek) }\end{array}$ & Rar. 291 & Complete \\
\hline $\begin{array}{l}\text { D-Mu (München, Universitätsbibliothek } \\
\text { der Ludwig-Maximilians-Universität) }\end{array}$ & 0014/W 2 Art. 269 & Complete \\
\hline
\end{tabular}




\begin{tabular}{|c|c|c|}
\hline Location & Shelfmark & Condition \\
\hline $\begin{array}{l}\text { D-W (Wolfenbüttel, Herzog August } \\
\text { Bibliothek) }\end{array}$ & A: 12.9 Poet. $2^{\circ}(4)$ & Complete \\
\hline $\begin{array}{l}\text { DK-Kk (Copenhagen, Det Kongelige } \\
\text { Bibliotek) }\end{array}$ & U292, mu 6603.0131 & Complete \\
\hline F-CO (Colmar, Bibliothèque municipale) & XI 10979 & No information available \\
\hline F-SEL (Sélestat, Bibliothèque municipale) & K 1132d Incunables & No information available \\
\hline $\begin{array}{l}\text { GB-Ge (Glasgow, University Library, } \\
\text { Euing Music Collection) }\end{array}$ & Sp Coll R.x.57 & No information available \\
\hline GB-Lbl (London, British Library) & Hirsch III.1130 & Complete \\
\hline GB-Lbl (London, British Library) & K.1.i.17. & Complete \\
\hline $\begin{array}{l}\text { I-Bc (Bologna, Museo internazionale e } \\
\text { biblioteca della musica di Bologna) }\end{array}$ & Q.112/B & No information available \\
\hline $\begin{array}{l}\text { PL-WRu (Wrocław, Biblioteka } \\
\text { Uniwersytecka) }\end{array}$ & 407078 & Complete \\
\hline S-L (Lund, Universitetsbiblioteket) & $\begin{array}{l}\text { Fol Utl Vitt Nylat = } \\
\text { Guntherus }\end{array}$ & Complete \\
\hline S-Sk (Stockholm, Kungliga biblioteket) & RAR: $147 \mathrm{~F}$ & No information available \\
\hline $\begin{array}{l}\text { US-Cn (Chicago, IL, The Newberry } \\
\text { Library) }\end{array}$ & $\begin{array}{l}\text { VAULT Case VM } \\
1490 . \mathrm{T} 83 \mathrm{~m}\end{array}$ & Complete \\
\hline $\begin{array}{l}\text { US-NYp (New York, NY, New York } \\
\text { Public Library at Lincoln Center, Music } \\
\text { Division) }\end{array}$ & JOG 94-6 & $\begin{array}{l}\text { Folio } 1 \text { is separate and does not } \\
\text { seem to belong to this copy. Folio } \\
\text { [A10] is missing. }\end{array}$ \\
\hline $\begin{array}{l}\text { US-R (Rochester, NY, University, } \\
\text { Eastman School of Music, Sibley Music } \\
\text { Library) }\end{array}$ & M1490.T839M & Complete \\
\hline $\begin{array}{l}\text { US-Wc (Washington, D.C., Library of } \\
\text { Congress, Music Division) }\end{array}$ & $\begin{array}{l}\text { Rosenwald } \\
\text { Collection }\end{array}$ & No information available \\
\hline
\end{tabular}

\section{Appendix 4.2 Transcription of a song celebrating Luther's burning of the papal bull, 1520, from the copy of Melopoiae in Chicago, The Newberry Library, VAULT Case VM 1490.T83m, fol. $2^{\mathrm{v}}$}

Vive vive mi Luthere

Cuncti tibi dicant $\chi \alpha \tilde{\rho} \rho \varepsilon$

Veritatis columen. Io Io

Leti este Lutherani

Nam uos estis Christiani

Antichristum temnite. Io Io

Vobis illucescit lumen

Quod ab alto dedit numen

Fugite scholasticos. Io Io

Libertatem Christianam

Non existimantes vanam

Fortiter defendite. Io Io 
Nil nocebit bulla minax

Veritatem timet fugax

Sathane invencio. Io Io

Plange Roma fraudulenta

Bulla iacet virulenta

Et famesa/ [sc. famesce] curia. Io Io

Reum querunt nunc papistae

Regnum perit antichristi

Cum corona triplici. Io Io

Veniarum nundinator

Fidei depopulator

Resipisce Pontifex. Io Io

Si te ventris onus urget

Ius combustum nates purget

Cum sit antichristicum. Io Io

Nomen vestri iam patroni

Scire vultis Curtisani

Danielem legite. Io Io

\section{Notes}

1 Melopoiae sive harmoniae tetracenticae (Augsburg: Erhard Oeglin, 1507), vdm 55. For a recent, comprehensive assessment of this publication see Lodes, 'Concentus, Melopoiae und Harmonie'.

2 See Andrea Lindmayr-Brandl's chapter in this book.

3 The paratexts are: two poems by Konrad Celtis (fol. A1 ${ }^{\mathrm{r}}$ ); poem to the printer Erhard Oeglin (fol. A9v); poem by Dietrich Ulsenius to Celtis (fol. A10v). The illustrations are: woodcut of Apollo on Parnassus (fol. $3^{\mathrm{r}}$ ), woodcut of Jupiter, Phoebus and Pegasus flanked by Mercury and Pallas Athena, surrounded by the nine Muses, with the arms of Celtis (fol. 10 $)$. For more information on the details of the publication, see $v d m$.

4 See Lodes, 'An anderem Ort'.

5 Hartmann, Die humanistische Odenkomposition, 7-14.

6 Lodes, 'Concentus, Melopoiae und Harmonie', 56-57.

7 Bobeth, 'Die humanistische Odenkomposition' 70. On further changes in this edition also see Schwindt, 'Asmatographi'.

8 Bobeth, 'Die humanistische Odenkomposition', 68. For early sources also see Brinzing, Neue Quellen.

9 Royston Gustavson, 'The Music Editions of Christian Egenolff', 154-155 and catalogue no. 1, 175-176. A second, simultaneous issue of the title was published with a tenor title page beginning Melodiae. They are part of the same edition. See Gustavson, 'The Music Editions of Christian Egenolff', 175.

10 Gustavson, 'The Music Editions of Christian Egenolff', 165, and catalogue Nr 11, 184-185.

11 Utilis et compendiaria introductio (Vienna: [Johann Singriener the Elder], [1523]), vdm 70; see also Kirnbauer, 'Lieder ohne Worte'.

12 For these lute sources see McDonald, 'The Metrical Harmoniae', 73 fn. 8.

13 For example, Odae cum harmoniis (Braşov: Johannes Honterus, 1548), vdm 1505, in which the Lutheran reformer Johannes Honterus included three of Tritonius' settings. See McDonald, 'Notes on the Sources', 627.

14 Libellus ex arte versificatoria (Wittenberg: Georg Rhau, 1533), vdm 99. For later editions see vdm; Johannes Spangenberg, Prosodia in usum iuventutis Northusianae (Wittenberg: Georg Rhau, 1535), vdm 92; Johannes Spangenberg, Grammaticae latinae partes (Nuremberg: Johann Petreius, 1539), vdm 145 . 
15 For a description of all three see Bobeth, 'Die humanistische Odenkomposition', 71-87, and Brinzing, Neue Quellen.

16 Bobeth, 'Die humanistische Odenkomposition', 83.

17 If this was, in fact, copied in southern Moravia on 16 August 1507, it would point to a circulation of Tritonius' ode settings before the printing of the Melopoiae. See McDonald, 'The Metrical Harmoniae', 72 .

18 Harmoniae hymnorum scholae gorlicensis (Görlitz: A. Fritsch, 1587), RISM B/I 1587'15; see McDonald, 'Notes on the Sources', 630.

19 For this, also see Horz, 'Hymnen und Metrik um 1500'.

20 For Senfl, see McDonald, 'The Metrical Harmoniae', and McDonald, 'Notes on the Sources'. For Grefinger see McDonald, 'The Metrical Harmoniae', and Müller, 'Eine Humanistenode Wolfgang Gräfingers'. A further example is the five-voice quantitative setting, in which the tenor is loosely based on Tritonius' setting of Iam satis nivis, in Rhythmus Codri Urcei in die divi Martini pronunciatus (Erfurt: Hans Knappe the Elder, 1514), vdm 645. See McDonald, 'The Cult of Luther in Music'.

21 For these, see in particular McDonald, 'The Metrical Harmoniae'. Grefinger perhaps set more Horatian odes; a setting of the Horatian ode I.4 (Solvitur acris hiems) has survived, copied in the margins of Vadian's copy of Horatii Flacci lyrici poetae opera (Venice: Donnino Pinzi, 1405 [=1505]) now in the Kantonsbibliothek St Gallen [VadSlg Inc 714]. See Müller, 'Eine Humanistenode Wolfgang Gräfingers'.

22 See McDonald, 'The Metrical Harmoniae'; McDonald, Paul Hofhaimer.

23 See Tröster, 'Theobald Billican and Michael's Ode Settings in Print'. Some further, now lost, ode publications are mentioned by Tröster, 226.

24 McDonald, 'Notes on the Sources', 632.

25 Bobeth, 'Die humanistische Odenkomposition', 70.

26 Lodes, 'Concentus, Melopoiae und Harmonie', 43. Previously, this idea was explored at length by McDonald, 'Orpheus Germanicus', 174-190.

27 Nicole Schwindt has recently aimed to differentiate the 'pedagogical' use of the Harmonie and pointed to its potential use by adult members of a courtly or literary society. See Schwindt, 'Asmatographi'.

28 GB-Lbl, Hirsch III 1128.

29 Of the copies of Melopoiae which I have examined (as originals or scans), the following have no manuscript additions or corrections: A-Wn [SA.76.A.3], B-Br, D-As, D-B, D-Mbs, DK-Kk, GBLbl [K.1.i.17.], PL-WRu, US-R. According to information obtained by the libraries, the following copies also include no annotations: A-Z, D-FRu, US-NYp. I have no information about: F-CO, F-SEL, GB-Ge, S-Sk. Birgit Lodes furthermore reports that the copies in I-Bc and D-W have no manuscript additions. Lodes, 'Concentus, Melopoiae und Harmonie', 57.

30 See Lodes, 'Concentus, Melopoiae und Harmonie', 42. On Celtis' conscious imitation of Horace, see also Auhagen et al., Horaz und Celtis.

31 See Lodes, 'Concentus, Melopoiae und Harmonie', 50 as well as Luh, Kaiser Maximilian gewidmet.

32 Lodes, 'Concentus, Melopoiae und Harmonie', 47; further on Celtis' own odes also see Luh, Kaiser Maximilian gewidmet.

33 Lodes, 'Concentus, Melopoiae und Harmonie' 43-46.

34 Simon Minervius, dedication of Ludwig Senfl, Varia Carminum genera (Nuremberg: Formschneider, 1534). For the transcription and translation see McDonald, 'The Metrical Harmoniae', $141-142$.

35 See Brinzing, Neue Quellen, 8.

36 Lodes, 'Concentus, Melopoiae und Harmonie', 35. Also Pirker, 'Beiträge zur Entwicklungsgeschichte'.

37 Melopoiae, fol. $1^{\mathrm{r}}$.

38 Johannes Cochlaeus, Tetrachordum musices (Nuremberg: Johann Weißenburger, 1511), vdm 128, fol. F2'; also referenced in Staehelin, 'Horaz in der Musik der Neuzeit', 198.

39 Horace, Carmina IV.9, 4. Cited after Staehelin, 'Horaz in Musik der Neuzeit', 198.

$40 \mathrm{McD}$ onald, 'The Metrical Harmoniae', 83.

41 Melopoiae, fol. $1^{\mathrm{r}}$.

42 Hankins, 'Humanism and Music in Italy', 252-257. See also Wilson, 'Canterino and improvvisatore', 292-310.

43 Grafton, 'The Humanist as Reader', 186.

44 The double purpose of practical use and humanist ideal is also made clear in Horz, 'Heinrich Glarean', 176-178. 
45 Horz, 'Hymnen und Metrik'.

46 McDonald, 'Orpheus Germanicus', 26.

47 See in particular Lodes, 'Concentus, Melopoiae und Harmonie', 56-57, who examined copies $\mathrm{CH}-\mathrm{Bu}, \mathrm{I}-\mathrm{Bc}, \mathrm{B}-\mathrm{Br}, \mathrm{DK}-\mathrm{Kk}, \mathrm{GB}-\mathrm{Lbl} \mathrm{D}-\mathrm{Mbs}$, A-Wn, D-W for the presence of manuscript additions.

48 Bobeth, 'Die humanistische Odenkomposition', 69.

49 On collecting also see Giselbrecht, 'To Have and to Hold'.

50 Concentus harmonici quattuor missarum (Basel: Gregor Mewes, [1507]), vdm 630. The copy in $\mathrm{CH}-\mathrm{Bu}$ (Shelfmark KK III 23a) has all four partbooks. There is a single altus partbook in D-HBa (Shelfmark L003M-XLIX-1).

51 Aus sonderer künstlicher Art (Augsburg: Erhard Oeglin, 1512), vdm 11, survives in two complete copies (D-Mbs, GB-Lbl) and two partbooks in A-Wn. [Sixty-eight songs] ([Augsburg]: [Erhard Oeglin], [c. 1512-1513]), vdm 14, survives in a single partbook in D-B.

52 See the chapter by Gustavson in this book.

53 Liber selectarum cantionum quas vulgo mutetas appellant (Augsburg: Sigmund Grimm \& Marx Wyrsung, 1520), vdm 18.

54 These are the copies in CH-Bu and US-NYp. CH-SG lacks pages 9-12.

55 A-Wn 53.C.26; bound at the end are a number of woodcuts.

56 The A-Wn copy of the Ligurinus is somewhat of an oddity. First, it is one of the few copies in which the two woodcuts have not been removed. Assmann suggests most were removed by Peutinger before distribution. Second, it includes further woodcuts at the end, mainly from the Quatuor libri amorum, printed in 1502. For more information, see Assmann, Gunther der Dichter, 19-27.

57 A-Su, shelfmark F II 475.

58 Chapman, 'Printed Collections of Polyphonic Music', 82.

59 For more on Schedel's library, see most recently Bayerische Staatsbibliothek, Welten des Wissens.

60 Bayerische Staatsbibliothek, Welten des Wissens, 101.

61 Ibid., 46.

62 D-Mbs Clm 263, 126r-160'; D-B Co. germ. 2 447, 255-277. For both, see Stauber, Die Schedelsche Bibliothek.

63 Kirnbauer, Hartmann Schedel und sein 'Liederbuch'.

64 See Stauber, Die Schedelsche Bibliothek, 107.

65 See Kirnbauer, Hartmann Schedel und sein 'Liederbuch', 102-108. For the Sebald hymn also see McDonald, 'Orpheus Germanicus', 184.

66 Konrad Celtis, Ludus Dianae (Nuremberg: Hieronymus Höltzel, 1501), vdm 59, copy D-Mbs 4 Inc.c.a. 1723\#Beibd.4.

67 Scaenica progymnasmata ([Basel]: Johann Bergmann von Olpe, 1498), vdm 73, copy D-Mbs 4 Inc.c.a. 1542 n; and Scaenica progymnasmata (Tübingen: Thomas Anshelm, 1511), vdm 77, copy D-Mbs Res/4 P.o.lat. 756,23.

68 Urceo Codro, Rhythmus die divi Martini pronunciatus (Wittenberg: Johann Grunenberg, 1511), vdm 95, copy D-Mbs Res. $4^{\circ}$ P.o.lat. 743 26. See also: McDonald, 'The Cult of Luther in Music', 206, 207, 222.

69 Unfortunately none is specifically named in Schedel's catalogues, which would allow a better understanding of where he located them in his system of knowledge and learning. This is not unusual, as many of the entries evidently refer to collected volumes, but only name one or a few of the individual titles.

70 Lodes, 'Concentus, Melopoiae und Harmonie', 46.

$71 \mathrm{I}$ am grateful to Åsa Sjöblom (University Library Lund) for this information.

72 The inscription reads 'Conradus Celtis primus poeta germanicus in carmine lirico presertim non mediocriter doctus/ Obijt . $\mathrm{M}^{\mathrm{o}}$. $\mathrm{d}^{\mathrm{o}}$.viiij ${ }^{\circ}$. Wienne/ me Gregorio Nitsch canonico Olomucensem tunc illis constituto et illius parentalibus interessente/ Hic me paulo ante obitum suum hoc libro donauit vivat deo eterno'.

73 I am grateful to Dr. Marcus Schröter (University Library Freiburg) for information about this copy.

74 PL-WRu, shelfmark 407078.

75 This name is accompanied by the inscription: 'Take care not to spurn the stars if you derive your life from the stars' ('Caue astra spernas vitam qui ducis ab astris'). 
76 The USTC lists 120 titles in folio, versus nineteen in quarto, nineteen in octavo and one in sextodecimo.

77 CH-SGs Barocksaal SGST DD Mitte III 6 (K9); also Ink 397.

78 They are now in a binding from the eighteenth century, which likely replaced an earlier binding. The inscription on the fore-edge of the entire volume looks to be from a sixteenth-century binding. Moreover, annotations in a sixteenth-century hand can be found in all volumes. I am grateful to M.A. Sabine Bachofner (Stiftsbibliothek St. Gallen) for her help and detailed discussion of this volume.

79 For another use, also see Brinzing, Neue Quellen, 14-15.

80 Diogenes Laertius, Vitae et sententiae philosophorum (Venice: Philippus Pincius, 1497); Aulus Gellius, Noctes Atticae (Venice: Boneto Locatelli for Octavian Scotus, 1494), A-Z StiBZ Inc. I/138. I am grateful to Dr. Andreas Gamerith (Stiftsbibliothek Zwettl) for this information.

81 D-Mu W2 Art. 269. I am grateful to Dr. Sven Kuttner (Universitätsbibliothek München) for his detailed information on the copy. His suggestions that this was Heinrich Glarean's personal copy is however probably incorrect, given the handwriting and in particular the level and content of the annotations. I am grateful to Prof. Iain Fenlon for sharing his expertise in identifying Glarean's books.

82 On the music pages we only find two changes: in the tenor of Sic te diva one pitch is corrected and the b-flat crossed out. Moreover, the first word of the twenty-second setting, Floreat in studiis, is entered by hand in the tenor voice.

83 GB-Lbl Hirsch III.1130.

$84 \mathrm{On} \mathrm{fol.} 7^{\mathrm{r}}$ in the first system of the bassus, a fermata has been added. Further text was also added on the bottom of fol. $2^{\mathrm{v}}$, which is unfortunately too faded to read.

$85 \mathrm{CH}-\mathrm{Bu}$ kk I 27.

86 For more on the manuscript, see Kmetz, Die Handschriften der Universitätsbibliothek Basel, 42-45.

87 US-Cn VAULT Case VM 1490.T83m. I am grateful to Katie Bank and Grantley McDonald, who brought it to my attention.

88 First published in Ludwig Senfl, Varia carminum genera (Nuremberg: Hieronymus Formschneider, 1534), vdm 97. Another setting by Senfl was included in Hofhaimer's Harmoniae poeticae (Nuremberg: Johannes Petreius, 1539).

89 Two different versions by Benedict Ducis are included in Geminae undeviginti odarum Horatii melodiae (Frankfurt am Main: Christian Egenolff, 1551), RISM B/I $1551^{17}$.

90 In Isagogicus rerum grammaticarum (Erfurt: Melchior Sachse the Elder, 1548), vdm 1518. Later it is included with a different text in $1551^{17}$. On this also see Tröster, 'Theobald Billican and Michael's Ode Settings', 237.

91 A three-voice setting is included in De partium orationis adcidentibus compendium, Marburg: [Franz Rhode], 1531, vdm 138. See Tröster, 'Theobald Billican and Michael's Ode Settings', 243.

92 For further examples of this practice in the early sixteenth century, see Giselbrecht, 'Manuscript and Print Combined'.

93 See, for example, Kawerau, '3. Ein Lied auf die Verbrennung'.

94 The full title is: CARMEN VICTORIALE IN SOLENNEM illum actum quo D Martinus Lutherus X die Decembris, anno domini M.D. XX. VVittembergae ante portam S Crucis, Jus Canonicum \& omnia Papistica Decreta cum Decretalibus combussit. Cited after the transcriptions of this source in 'Actenstück zur Reformationsgeschichte', and Kawerau, 'Ein Lied auf die Verbrennung', 232-233. Volz questioned Kawerau's assertion that the single surviving copy of this sheet belonged to Luther and carries annotations in his hand on the basis of the handwriting; see Volz, 'Lutherana'. The text in Chicago differs from that on the broadsheet in several ways: the Chicago source has an additional strophe between strophes 2 and 3 of the broadsheet, but does not have what is strophe 6 (Iam primatus ille) in the broadsheet. The order of strophes 7 and 8 is also reversed.

95 This version is different from both others described here, with a variant beginning and end, and only eight strophes.

96 Nikolaus Selnecker, Confessio Augustana oratio historica de initiis, causis, et progressu (Jena: Tobias Steinmann, 1592), fol. E4 .

97 This version does contain the same verse as US-Cn between strophes 2 and 3 that is not in the broadsheet (starting with 'Nobis'). The version in the Oratio includes an additional strophe starting with 'Iam primatus ille', but not the strophe starting 'Plane Roma'. 
98 GB-Lbl K.1.i.17. 'Georginus [or Georgius?] Kloss M.D. Francforti ad Moenum'.

99 This resulted in the publication of his Catalogue of One Hundred Works. Parts of his collection are now held at Senate House Library, London. I am grateful to David Coppen (Sibley Music Library, Eastman School of Music, Rochester) for providing me with a scan and additional information about this copy.

100 I am grateful to Dr. Roland Schmidt-Hensel (Staatsbibliothek Berlin) for the detailed information on this copy.

\section{References}

'Actenstück zur Reformationsgeschichte'. Allgemeine Kirchen-Zeitung 7/8 (1828): cols. 69-70.

Assmann, Erwin, ed. Gunther der Dichter. Ligurinus. Hanover: Hahnsche Buchhandlung, 1987.

Auhagen, Ulrike et al., eds. Horaz und Celtis. Tübingen: G. Narr, 2000.

Bayerische Staatsbibliothek, ed. Welten des Wissens. Die Bibliothek und die Weltchronik des Nürnberger Arztes Hartmann Schedel (1440-1514). Munich: Allitera Verlag, 2014.

Bobeth, Gundela. 'Die humanistische Odenkomposition in Buchdruck und Handschrift: Zur Rolle der Melopoiae bei der Formung und Ausbreitung eines kompositorischen Erfolgsmodells'. In NiveauNischeNimbus: Die Anfänge des Musikdrucks nördlich der Alpen, edited by Birgit Lodes. Wiener Forum für ältere Musikgeschichte 3. Tutzing: Hans Schneider, 2010, 67-87.

Brinzing, Armin. Neue Quellen zur Geschichte der humanistischen Odenkomposition in Deutschland. Nachrichten der Akademie der Wissenschaften zu Göttingen I. Philologisch-Historische Klasse 8: Kleinüberlieferung mehrstimmiger Musik vor 1550 in deutschem Sprachgebiet 5. Göttingen: Vandenhoeck \& Ruprecht, 2001.

Chapman, Catherine Weeks. 'Printed Collections of Polyphonic Music Owned by Ferdinand Columbus'. Journal of the American Musicological Society 21 (1968): 34-84.

Giselbrecht, Elisabeth. 'Manuscript and Print Combined: Re-discovered Manuscript Additions in the Kraków Copy of Peter Schöffer's Third Songbook (1536)'. In 'Teutsche Liedlein' des 16. Jahrhunderts, edited by Susanne Rode-Breymann and Achim Aurnhammer. Wolfenbütteler Abhandlungen zur Renaissanceforschung 35. Wiesbaden: Harrassowitz, 2018, 117-136.

Giselbrecht, Elisabeth. 'To Have and to Hold: Music Books as Collectables'. In Sources of Identity, edited by Lisa Colton and Tim Shephard. Turnhout: Brepols, 2016, 239-260.

Grafton, Anthony. 'The Humanist as Reader'. In A History of Reading in the West, edited by Guglielmo Cavallo and Roger Chartier, translated by Lydia G. Cochrane. Oxford: Polity Press, 1995, 179-212.

Gustavson, Royston. 'The Music Editions of Christian Egenolff. A New Catalogue and Its Implications'. In Early Music Printing in German-Speaking Lands, edited by Andrea Lindmayr-Brandl, Elisabeth Giselbrecht and Grantley McDonald. London and New York: Routledge, 2018, 153-195.

Hankins, James. 'Humanism and Music in Italy'. In The Cambridge History of Fifteenth-Century Music, edited by Anna Maria Busse Berger and Jesse Rodin. Cambridge: Cambridge University Press, 2015, 231-262.

Hartmann, Karl-Günther. Die humanistische Odenkomposition in Deutschland. Vorgeschichte und Voraussetzungen. Erlangen: Palm \& Enke, 1976.

Horz, Andrea. 'Heinrich Glarean und der humanistische Odengesang'. MusikTheorie 27 (2012): 176-190.

Horz, Andrea. 'Hymnen und Metrik um 1500 im deutschsprachigen Raum'. In Senfl-Studien 3, edited by Birgit Lodes, Stefan Gasch and Sonja Tröster. Vienna: Hollitzer, 2019, 85-100.

Kawerau, Gustav. '3. Ein Lied auf die Verbrennung der Bannbulle'. Archiv für Reformationsgeschichte 6 (1909): 232-233. 
Kirnbauer, Martin. Hartmann Schedel und sein 'Liederbuch'. Studien zu einer spätmittelalterlichen Musikhandschrift (Bayerische Staatsbibliothek München, Cgm 810) und ihrem Kontext. Bern and New York: Peter Lang, 2001.

Kirnbauer, Martin. 'Lieder ohne Worte. Hans Judenkünigs Lautentabulaturen von 1523'. In Kulturund kommunikationshistorischer Wandel des Liedes im 16. Jahrhundert, edited by Albrecht Classen, Michael Fischer, and Nils Grosch. Münster: Waxmann, 2012, 155-168.

Kmetz, John. Die Handschriften der Universitätsbibliothek Basel. Katalog der Musikhandschriften des 16. Jahrhunderts: quellenkritische und historische Untersuchung. Basel: Universitätsbibliothek Basel, 1988.

Littleton, Alfred Henry. Catalogue of One Hundred Works Illustrating the History of Music Printing from the Fifteenth to the End of the Seventeenth Century in the Library of Alfred Henry Littleton. London: Novello, 1911.

Lodes, Birgit. 'An anderem Ort, auf andere Art: Petruccis und Mewes' Obrecht-Drucke'. Basler Jahrbuch für Historische Musikpraxis 25 (2002): 85-111.

Lodes, Birgit. 'Concentus, Melopoiae und Harmonie 1507: Zum Geburtsjahr des Typendrucks mehrstimmiger Musik nördlich der Alpen'. In NiveauNischeNimbus: 500 Jahre Musikdruck nördlich der Alpen, edited by Birgit Lodes. Wiener Forum für ältere Musikgeschichte 3. Tutzing: Hans Schneider, 2010, 33-66.

Luh, Peter. Kaiser Maximilian gewidmet: Die unvollendete Werkausgabe des Conrad Celtis und ihre Holzschnitte. Frankfurt am Main: Peter Lang, 2001.

McDonald, Grantley. 'The Cult of Luther in Music'. In Early Music Printing in German-Speaking Lands, edited by Andrea Lindmayr-Brandl, Elisabeth Giselbrecht and Grantley McDonald. London and New York: Routledge, 2018, 199-224.

McDonald, Grantley. 'The Metrical Harmoniae of Wolfgang Gräfinger and Ludwig Senfl in the Conjunction of Humanism, Neoplatonism, and Nicodemism'. In Senfl-Studien 1, edited by Stefan Gasch, Birgit Lodes and Sonja Tröster. Wiener Forum für ältere Musikgeschichte 4. Tutzing: Hans Schneider, 2012, 69-148.

McDonald, Grantley. 'Notes on the Sources and Reception of Senfl's Harmoniae'. In Senfl-Studien 2, edited by Stefan Gasch and Sonja Tröster. Wiener Forum für ältere Musikgeschichte 7. Tutzing: Hans Schneider, 2013, 623-633.

McDonald, Grantley. 'Orpheus Germanicus: Metrical Music and the Reception of Marsilio Ficino's Poetics and Music Theory in Renaissance Germany.' Ph.D. dissertation, University of Melbourne, 2002.

McDonald, Grantley, ed. Paul Hofhaimer. Harmoniae poeticae (1539). Denkmäler der Musik in Salzburg 15/IV. Munich: Strube Verlag, 2014.

Müller, Clemens. 'Eine Humanistenode Wolfgang Gräfingers, notiert von Joachim Vadian'. In Senfl-Studien 1, edited by Stefan Gasch, Birgit Lodes and Sonja Tröster. Wiener Forum für ältere Musikgeschichte 4. Tutzing: Hans Schneider, 2012, 149-160.

Pirker, Renatus. 'Beiträge zur Entwicklungsgeschichte der vierstimmigen Humanistenode'. Musicologica Austriaca 1 (1977): 136-153.

Schwindt, Nicole. 'Maximilians deutsche und lateinische »asmatographi«. Zur musikalischen Liedkultur in Druck und Handschrift um 1500'. In Buchkulturen des deutschen Humanismus (1430 1530). Netzwerke und Kristallisationspunkte. Bericht über die Tagung Berlin 9.-12. März 2011, edited by Falk Eisermann, Anne Eusterschulte, Eef Overgaauw, and Elke Werner. Studies in Medieval and Reformation Tradition. Leiden: Brill (forthcoming).

Staehelin, Martin. 'Horaz in der Musik der Neuzeit'. In Geschichte des Textverständnisses am Beispiel von Pindar und Horaz, edited by Walther Killy. Wolfenbütteler Symposion. Munich: Kraus International, 1981, 195-217. 
Stauber, Richard. Die Schedelsche Bibliothek: ein Beitrag zur Geschichte der Ausbreitung der italienischen Renaissance, des deutschen Humanismus und der medizinischen Literatur. Nieukoop: B. de Graaf, 1969.

Tröster, Sonja. 'Theobald Billican and Michael's Ode Settings in Print: Notes on an Exceptional Transmission'. In Early Music Printing in German-Speaking Lands, edited by Andrea Lindmayr-Brandl, Elisabeth Giselbrecht and Grantley McDonald. London and New York: Routledge, 2018, 225-244.

Volz, Hans. 'Lutherana'. Archiv für Reformationsgeschichte 27 (1930): 111-113.

Wilson, Blake. 'Canterino and improvvisatore: Oral Poetry and Performance'. In The Cambridge History of Fifteenth-Century Music, edited by Anna Maria Busse Berger and Jesse Rodin. Cambridge: Cambridge University Press, 2015, 292-310. 